\title{
The Analysis of The Relationship Between Inflation, Unemployment And Economic Growth In Nigeria (1980-2014).
}

\author{
Nazifi Abdullahi Darma \\ Associate Professor of Development Economics. \\ University of Abuja, Nigeria.
}

\author{
Aliyu Musari Onimisi \\ Research Assistant \\ Centre for Economic Development and Policy Analysis, Abuja.
}

\begin{abstract}
This research work investigates the relationship between inflation, unemployment and economic growth in Nigeria (1980-2014). The objectives of the study is to examine the short run and the long run relationship between inflation, unemployment and economic growth in Nigeria. It begins with the application of Augmented Dickey-Fuller techniques to examine the unit root property of the time series data after which Autoregressive Distributive Lag Model (ARDL) was used to determine the cointegration or long-run relationship. Lastly, Vector Autoregressive (VAR) model test was conducted to investigate the causal relationship between the variables studied. Empirical findings from ARDL model shows that there is no short and the long run relationship between unemployment rate, inflation rate and real GDP growth rate in Nigeria. The results of VAR model do not indicate robust evidence and do not confirm an inverse linkage between unemployment rate and economic growth. In view of the foregoing, the study therefore recommends the adoption of fiscal measures that enhance economic growth and private sector activities, hence promoting economic growth and employment generation. In addition, key economic incentives are needed towards attracting foreign direct investment (FDI) in productive sectors of the national economy and expanding resource utilization base.
\end{abstract}

Keywords: Unemployment, Inflation, Economic growth and Okun's Law

\section{INTRODCTION}

Inflation and unemployment remain serious issues in any economy. It is part of the overall macroeconomic policy objectives that an economy maintain low rates of inflation and unemployment. Unarguably, parts of the macroeconomic goals which the government strives to achieve are the maintenance of stable domestic price level, stable economic growth and fullemployment. Macroeconomic performance is judged by three broad measures- unemployment rate, inflation rate, and the growth rate of output (Ugwuanyi, 2004).

Unemployed is a person who did absolutely nothing at all or did something but not for up to 20 hours in a week. Underemployment however occurs if a person work less than full time which is 40 hours but work at least 20 hours on average a week or a person that work full time but is engaged in an activity that underutilizes his/her skills, time, educational qualification and wages. (National Bureau Statistics, 2015). Inflation on the other hand, connotes the general increase in the price level and is broadly an average measure because at any point in time, prices may be increasing, decreasing or constant; a persistent increase in prices hurts the economy, particularly the poor who have little or no savings to cushion rising prices. It is even worse when uncertainty follows price increases (Nwaobi, 2009). 
Looking at the Nigerian data, the inflationary trend shows that it has been non-linear overtime. Inflation rate in Nigeria average 12.15 percent from 1996 until 2015, reaching an all-time high of 47.56 percent in January of 1996 and a record low of -2.49 percent in January of 2000 . Unemployment rate in Nigeria averaged 11.45 percent from 2006 until 2015, reaching an alltime high of 23.90 percent in the fourth quarter of 2011 and a record low of 5.30 percent in the fourth quarter of 2006. While the GDP Annual Growth Rate in Nigeria averaged 4.03 percent from 1982 until 2016, reaching an all-time high of 19.17 percent in the fourth quarter of 2004 and a record low of -7.81 percent in the fourth quarter of 1983. (National Bureau of Statistics, Nigeria, 2015).

\section{Statement of the Research Problems}

The Nigerian economy has remained largely underdeveloped despite its possession of vast human and natural resources. The per capita income is low, unemployment and inflation rates are high. The economic crisis ravaging the Nigerian economy lately has taken a new dimension. That is, the inability of some states government to pay salaries of workers which later resulted to bail-out by the Federal Government, and the decline of crude oil price in the international market which has contracted our foreign exchange earnings and creation of jobs for the teaming youth that are willing and able to work.

The situation in Nigeria is disturbing as various macroeconomic policies by government have been unable to results in sustained price stability, reduction in unemployment and economic growth. The economy has continued to witness recession since the emergence of Buhari-led administration. Hence, the fluctuations in the economy have confirmed the need for proactive strategies adoption towards economic management as a way of fast-tracking employment generating growth and development.

\section{Objectives of the Study}

The broad objective of this study is to empirically investigate the relationship between inflation, unemployment and economic growth in Nigeria. Other objectives of the study are:

1) To examine the short run causal relationship between inflation, unemployment and economic growth in Nigeria.

2) To examine whether there is long run relationship between inflation, unemployment and economic growth in Nigeria.

3) To examine whether economic growth has impact on unemployment in Nigeria.

\section{LITERATURE REVIEW}

Sa'idu B, et al. (2015) examines how unemployment and inflation substantially affect economic growth. The result of causality test suggests that unemployment does not granger causes economic growth and inflation, but economic growth and inflation Granger cause unemployment, also there exist Granger causality between economic growth and inflation. Therefore, the result suggests a one-way causation flowing from inflation to GDP.

Keshmeer M, et al. (2015) investigates whether long run association among growth and unemployment is relevant for Fiji for the period 1982-2012. Johansen Cointegration test procedure was applied to ascertain the association among growth, investment and unemployment. Result confirmed the evidence of long-run association among unemployment and growth, with cointegration running from investment and unemployment to increase in economic output. 
Fouzeia M, et al. (2015) investigates the relationship between growth and unemployment in Egypt. The results indicated there were no cointegration relationship between the variables of unemployment and GDP specifically implying there is no long-term relationship

Hussein Ali Al-Zeaud (2014) investigates the existence of trade-off relationship between unemployment and inflation in the Jordanian economy between 1984 and 2011. The results shown no causal relationship between unemployment and inflation in Jordan during the study period which means there is no trade-off relationship between the two variables.

Thayaparan A. (2014) examine the impact of inflation and economic growth on unemployment in Sri Lanka (1990-2012). The study discovered that unemployment granger caused by inflation. While, GDP does not granger cause unemployment. Unemployment and inflation both does not granger causes GDP growth rate, but unemployment and GDP growth rate both causes inflation.

Muhammad Aamir Khan (2013), investigates the link between the real GDP growth and unemployment, as described by Okun's law. The empirical analysis shows that a rise of one percentage point of unemployment is associated with a decline of 0.36 percentage point of real GDP growth.

Murat S, et al. (2014), estimate empirically the relationship between economic growth and unemployment rate in FYR of Macedonia applying the Okun's Law. Based on the VAR methodology and Engel-Granger cointegration test, she found no causal relationship between these two variables and a change in the growth rate of real GDP doesn't causes a change in the rate of unemployment and vice-versa.

\section{Sources of Data}

\section{METHODOLOGY}

The study used a sufficient length of secondary data ranging from 1980-2014 (34 years). The data were collected from different sources. Real GDP growth rate was sourced from the Central Bank of Nigeria (CBN) Statistical Bulletin from 1980-2015, while unemployment rate and inflation rate were collected from the National Bureau of Statistics (NBS), 1980-2015.

\section{Testing for the Order of Integration}

The Augmented Dickey-Fuller (ADF) test, (Dickey-Fuller 1986, 1981, 1979) is based on the stationary study of variable series on the following model (Pinn et al (2011):

$$
\Delta \mathrm{Y}_{\mathrm{t}}=\beta_{0}+\beta_{1} \mathrm{Y}_{\mathrm{t}-1}+\alpha_{\mathrm{i}} \sum \Delta \mathrm{Y}_{\mathrm{t}-\mathrm{i}}+\mu_{\mathrm{t}}
$$

Where: $\mathrm{t}$ is the linear trend, $\Delta \mathrm{Y}_{\mathrm{t}}=$ Differenced value of a given time series variable, $\beta_{0}=$ Constant parameter, $\beta_{1}=$ Coefficient of the first lag value of the series variable, $\mathrm{Y}_{\mathrm{t}-1}=$ First lag value of a series variable, $\alpha_{\mathrm{i}}=$ Coefficient of the lag values of the differenced time series, $\Delta \mathrm{Y}_{\mathrm{t}-\mathrm{i}}=$ Lag values of the differenced series variable, $\mu_{\mathrm{t}}=$ Error term. If the calculated ADF test statistics is less than the critical value, the null hypotheses $\left(\mathrm{H}_{0}\right)$ of a unit root cannot be rejected and the series is said to be non-stationary. The order of integration of $\mathrm{Y}$ is determined by conducting the ADF test on its first difference. The series will be integrated of order 1 if its first difference does not possess a unit root.

\section{Autoregressive Distributive Lag (ARDL) Model}

The Autoregressive Distributive Lag model (ARDL) is as follows: 
$\Delta \mathrm{UNEM}_{\mathrm{t}}=\lambda_{0}+\sum_{i=1}^{n} \quad \lambda_{1 \mathrm{i}} \Delta \mathrm{UNEM}_{\mathrm{t}-\mathrm{i}}+\sum_{i=1}^{n} \quad \lambda_{2 \mathrm{i}} \Delta \mathrm{RGDP}_{\mathrm{t}-\mathrm{i}}+\sum_{i=1}^{n} \quad \lambda_{3 \mathrm{i}} \Delta \mathrm{INFL}_{\mathrm{t}-\mathrm{i}}+\lambda_{4} \mathrm{RGDP}_{\mathrm{t}-1}+\lambda_{5} \mathrm{UNEM}_{\mathrm{t}-1}$ $+\lambda_{6} \mathrm{INFL}_{\mathrm{t}-1}+\phi \mathrm{ECM}_{\mathrm{t}-1}+\varepsilon_{\mathrm{t}}$

In the above model, $\Delta$ is the first-difference operator, and $\lambda s^{\prime}$ indicate long run coefficients and short run coefficients as represented, $\phi$ is the coefficient of Error Correction Mechanism (ECM), $\varepsilon_{\mathrm{t}}$ is the error/residual (white noise).

\section{Decision Rules}

The test of bound test is based on the F-test or Wald-test. F-test is to test the two following hypotheses as bellow:

$\mathbf{H}_{0}: \lambda_{4}=\lambda_{5}=\lambda_{6}=0$, no cointegration or long run relationship between the variables

$\mathbf{H}_{1}: \lambda_{4} \neq \lambda_{5} \neq \lambda_{6} \neq 0$ there is cointegration between the variables.

Since F-test does not have a standard distribution (non-standard distribution), the two critical values are given for the Upper Critical Bound (UCB) and Lower Critical Bound (LCB) (Pesaran et al, 2001). LCB value assumes all variables are $\mathrm{I}(0)$, meaning there is no cointegration between variables, while the UCB assumes all variables are I(1) which means that there is cointegration between variables. If the calculated $F$ value is greater than UCB, hypotheses $\mathrm{H}_{0}$ is rejected. Therefore, there is cointegration between the variables. The opposite is true if the calculated $\mathrm{F}$ value is smaller than the $\mathrm{LCB}$, this means that hypotheses $\mathrm{H}_{0}$ should be accepted. If the F calculated is between the LCB and UCB, this indicates that the result could not be ascertained.

\section{Short-Run Causality}

The short-run causality is thus determined from the ARDL model above (Eq-2);

$$
\begin{array}{llll}
\Delta \mathrm{UNEM}_{\mathrm{t}}=\phi_{0}+\sum_{i=1}^{n} & \phi_{1} \Delta \mathrm{UNEM}_{\mathrm{t}-\mathrm{i}}+\sum_{i=1}^{n} & \phi_{2} \Delta \mathrm{RGDP}_{\mathrm{t}-\mathrm{i}}+\sum_{i=1}^{n} & \phi_{3 i} \Delta \mathrm{INFL}_{\mathrm{t}-\mathrm{i}}+\lambda_{2} \mathrm{ECM}_{\mathrm{t}-1}+\varepsilon_{\mathrm{t} 1} \ldots . \\
\Delta \mathrm{RGDP}_{\mathrm{t}}=\psi_{0}+\sum_{i=1}^{n} & \psi_{1 \mathrm{i}} \Delta \mathrm{UNEM}_{\mathrm{t}-\mathrm{i}}+\sum_{i=1}^{n} & \Psi_{2 i} \Delta \mathrm{RGDP}_{\mathrm{t}-\mathrm{i}}+\sum_{i=1}^{n} & \Psi_{3 i} \Delta \mathrm{INFL}_{\mathrm{t}-\mathrm{i}}+\lambda_{1} \mathrm{ECM}_{\mathrm{t}-1}+\varepsilon_{\mathrm{t} 2} \ldots \\
\Delta \mathrm{INFL}_{\mathrm{t}}=\delta_{0}+\sum_{i=1}^{n} & \delta_{1} \Delta \mathrm{UNEM}_{\mathrm{t}-\mathrm{i}}+\sum_{i=1}^{n} & \delta_{2} \Delta \mathrm{RGDP}_{\mathrm{t}-\mathrm{i}}+\sum_{i=1}^{n} & \delta_{3} \Delta \mathrm{INFL}_{\mathrm{t}-\mathrm{i}}+\lambda_{3} \mathrm{ECM}_{\mathrm{t}-1}+\varepsilon_{\mathrm{t} 3} \ldots \ldots
\end{array}
$$

$\Delta$ is the difference operator, ECM representing the error - correction term derived from the long-run cointegrated relation from the above specified ARDL models. In equation 3, 4 and 5, $\lambda_{s}^{\prime}$ should exhibit a negative and significant sign for causality to exist in the long run.

Granger Causality relationship to test whether:

- Unemployment (UNEM) is the determinant to real GDP growth rate (UNEM- led RGDP) or otherwise, real GDP growth rate as the cause to unemployment (RGDP- led UNEM).

- Unemployment (UNEM) is the determinant to inflation rate (UNEM- led INFL) or vice versa, as INFL is the determinant to unemployment (INFL- led UNEM)

- Inflation (INFL) is the determinant to real GDP growth rate (INFL- led RGDP) or otherwise, as RGDP is the determinant to inflation (RGDP- led INFL).

\section{Vector Autoregressive (VAR) Model}

VAR models generalize the univariate autoregressive model by allowing for more than one evolving variable. All variables in a VAR enter the model in the same way each variable has an equation explaining its evolution based on its own lags and the lags of the other model variable. Therefore, the VAR framework for this study is as follows: 


$$
\begin{array}{cccc}
\mathrm{UNEM}_{\mathrm{t}}=\beta_{0}+\sum_{i=1}^{n} & \beta_{1} \mathrm{UNEM}_{\mathrm{t}-\mathrm{i}}+\sum_{i=1}^{n} & \beta_{2} \mathrm{RGDP}_{\mathrm{t}-\mathrm{i}}+\sum_{i=1}^{n} & \beta_{3} \mathrm{INFL}_{\mathrm{t}-\mathrm{i}}+\mathrm{U}_{\mathrm{t} 1} \ldots \ldots . . .(6) \\
\mathrm{RGDP}_{\mathrm{t}}=\beta_{0}+\sum_{i=1}^{n} & \beta_{1} \mathrm{UNEM}_{\mathrm{t}-\mathrm{i}}+\sum_{i=1}^{n} & \beta_{2} \mathrm{RGDP}_{\mathrm{t}-\mathrm{i}}+\sum_{i=1}^{n} & \beta_{3} \mathrm{INFL}_{\mathrm{t}-\mathrm{i}}+\mathrm{U}_{\mathrm{t} 2} \ldots \ldots . . . \\
\mathrm{INFL}_{\mathrm{t}}=\beta_{0}+\sum_{i=1}^{n} & \beta_{1} \mathrm{UNEM}_{\mathrm{t}-\mathrm{i}}+\sum_{i=1}^{n} & \beta_{2} \mathrm{RGDP}_{\mathrm{t}-\mathrm{i}}+\sum_{i=1}^{n} & \beta_{3} \text { INFL }_{\mathrm{t}-\mathrm{i}}+\mathrm{U}_{\mathrm{t} 3} \ldots \ldots \ldots . . .
\end{array}
$$

Where $\mathrm{UNEM}_{\mathrm{t}}$ is the unemployment rate, $\mathrm{RGDP}_{\mathrm{t}}$ is real GDP growth rate and INFL $_{\mathrm{t}}$ represent inflation rate, all at current period. While $\mathrm{UNEM}_{\mathrm{t}-1} \mathrm{RGDP}_{\mathrm{t}-1}$, INFL $\mathrm{t}$-i represents nth lag period of unemployment rate, real GDP growth rate and inflation rate respectively.

$\beta_{0}=$ Intercept of the VAR model

$\beta_{1} \beta_{2}$ and $\beta_{3}=$ coefficients

$\mathrm{U}_{\mathrm{t}}=$ error terms

\section{Decision Rules}

The VAR model is based on t-statistics and F- statistics. At 5 percent significance level, if the probability value of a particular explanatory variable is less than 5 percent, it means that the explanatory variable has significance impact on the dependent variable for the t-statistics. In the case of F-statistics, the wald-test is used to test the joint significance of the explanatory variables on the dependent variable.

\section{DISCUSSION OF FINDINGS}

The Augmented Dickey-Fuller (ADF) test revealed that real GDP growth rate is stationary at level $\{\mathrm{I}(0)\}$, while unemployment rate and inflation rate are both stationary after first difference $\{\mathrm{I}(1)\}$.

The optimal lag of one was selected as indicated by lag length selection criterion (Schwarz information criterion, Final prediction error and Hannan-Quinn information criterion). The result of bound test for cointegration in table 1 , indicates that null hypotheses cannot be rejected because the F- statistics(0.655646) is less than upper bound value (4.85) at 5 percent critical value for case III (Unrestricted intercept and no trend) as it is found in M. H. Pesaran, Y. Shin and R.J Smith critical table. Therefore, there is no long run relationship between inflation, unemployment and real GDP growth rate in Nigeria. Similar study conducted by Fouzeia, et al. (2015) observed that there is no long run relationship between unemployment and Gross Domestic Product (GDP) in Egypt.

Table-2 the VAR estimates indicate that real GDP growth rate in the previous year does not have significant relationship with current rate of unemployment, likewise inflation and unemployment. While, last year unemployment rate has significant impact of 99.20 percent on the current rate of unemployment.

\section{CONCLUSION AND RECOMMENDATIONS}

This study examines the relationship between inflation, unemployment and economic growth in Nigeria, 1980-2014. The ARDL bound test estimates of this study revealed that there is no long run relationship between the variables studied. Likewise, VAR estimates which indicates a non-significant relationship between economic growth and unemployment. In view of the foregoing results, new fiscal measures and strategies are needed to create massive employment and income. It is ideal that government at all levels should recognize the activities of rural farmers and motivate them towards diversification in order to reduce unemployment and raise output. Agricultural loans and other farm inputs such as fertilizer should be released 
on time and be made accessible to the rural farmers during farming season. To curb unemployment problems in Nigeria, access to power (electricity) through private provision and enhanced security are needed to spur domestic and foreign investment in the economy. Creation of a special bail-out fund for both private and public companies and industries that their collapse or closure have rendered their workforce jobless as a means of job creation and output expansion. Additional fiscal initiatives are needed to consolidate on the existing gains of the social intervention programme towards spurring private sector led production due its employment generation and positive externalities effect on the national economy.

\section{References}

Adawo, M. A.; Essien, E. B. and Ekpo, N. U. (2012). Is Nigeria's Unemployment Problem Unsolvable? Current Research Journal of Social Sciences, 4(6): 389-395.

Alanana O. (2003), "Youth unemployment in Nigeria, Some Implications for the third Millennium", Global Journal of Social Sciences 2 (1): 21-26.

Aminu, U. and A.Z. Anono (2012). An empirical Analysis of The Relationship between Unemployment and Inflation in Nigeria from 1977-2009. Business Journal, Economics and Review, Vol.1 (12), pp 4261. Global Research Society. Pakistan.

Aminu, U. and A.Z. Anono (2012). Effect of Inflation on the Growth and Development of the Nigerian Economy (An Empirical Analysis). International Journal of Business and Social Science. Vol.3 No.10 [Special Issue- May 2012].

Arewa A. and Nwakanma P. (2012), "Potential-real GDP and Growth Process of Nigerian Economy, An Empirical Re-evaluation of Okun's Law", European Scientific Journal, 8(9): 25-33.

Bakare, A.S. (2012). Stabilization policy, Unemployment Crises and Economic Growth in Nigeria. Universal Journal of Management and Social Sciences. Vol. 2, No.4.

Beaton K. (2010), “Time Variation in Okun's Law: A Canada and U.S. Comparison.” Bank of Canada Working Paper No. 2010-7, Bank of Canada, Retrieved: www.bankofcanada.ca/wpcontent/uploads/2010/05/wp10-7.

Central Bank of Nigeria, 1980-2015. Annual Report and Statement of Account. CBN Publications.

Central Bank of Nigeria, 1980-2015. Statistical bulletin. Abuja: Central Bank of Nigeria

Chang-shuai, L. and L. Zi-juan, (2012). Study on the relationship among Chinese unemployment rate, Economic growth and Inflation. Advances in Applied Economics and Finance, Vol.1, No.1.World science Publishers. United States.

Christopoulos D. (2004), "The Relationship between Output and Unemployment: Evidence from Greek Regions Study", Regional Science, 83: 611-620, DOI: 10.1007/s10110- 004-0198.

Falae S. O. (1971) Unemployment in Nigeria. Nigerian Journal of Economics and Social Studies. 13(1), pp. 65.

Fakhri, H. (2011). Relationship between Inflation and Economic Growth in Azerbaijani Economy: Is there any threshold effect? Asian Journal of Business and Management Sciences Vol.1 (1).

Fatukasi, B., (2011). Determinants of inflation in Nigeria: An empirical analysis. International Journal of Humanities and Social Science, 1(18): 262-271.

Friedman, M. (1977). Nobel lecture, Inflation and Unemployment. Journal of Political Economies, 85: 451-472.

Hussain, T., Siddiqi, M. W., \& Iqbal, A. (2010). A Coherent Relationship between Economic Growth and Unemployment: An Empirical Evidence from Pakistan. International Journal of Human and Social Sciences, 5(5),

Irfan, L., Sulaiman, D.M., Jalil, A., Hussain, A. (2010). “Test of Okun's law in some Asian countries co-integration approach", Europpean Journal of Scientific Research, Vol. 40, No. 1, pp. 73-80

Kemi, F., \& Dayo, B. (2015). Unemployment and Economic Growth in Nigeria. International Journal of African and Asian Study, ISSN 2409-6938, Vol 11, 2015.

Keynes, J. M. (1936). The General Theory of Employment, Interest, and Money, Harvest Brace Jovanovich, New York and London (reprinted in 1964 edition).

Khan, A. Q. K., Khattak, N. U. R. K., \& Hussain, A. H. (2008). Inter dependencies and Causality in the Macroeconomic Variables: Evidence from Pakistan (1960-2005). Sarhad J. Agric. 24 (1): 199-205. 
Lawanson, O. I. (2003). High Rate of Unemployment in Nigeria: The Consequences on Human Resource Management, 7 th Global Conference on Business and Economics, held at Rome, Italy on October, $13^{\text {th }}-14^{\text {th }}$

Moosa, I., (2008). “Economic growth and unemployment in Arab countries: Is Okun's law Valid?” Proceedings of the International Conference on the Unemployment Crisis in the Arab Countries. Mar. 17-18, Cairo- Egypt, pp: 119.

Miljovski, J. and Stojkov, A. (2012). "The natural rate of unemployment and the unemployment in the RM" Proceedings of the scientific symposium in honor of the $100^{\text {th }}$ birth anniversary of Academician Kiril Miljovski.

Naimy, V. Y. (2005). Unemployment in Lebanon: Application of Okun's Law. Journal of Business \& Economics Research, 3(10), 25-32.

Neely, C. J. (2010). Okun's Law: Output and Unemployment. Economic Synopses 4, 1-2. Saint Louis, MO: Federal Reserve Bank of St. Louis.

Nwaobi, G. C. (2009). "Inflation, Unemployment and Nigeria Families: An Empirical Investigation”, Publication of Quantitative Economic Research Bureau Nigeria, MPR paper No.14596.

Nwaobi, G.C., (2009). Inflation, unemployment and Nigeria families: An empirical investigation. Publication of Quantitative Economic Research Bureau Nigeria MPR Paper No. 14596.

Ola- David, O. and S. Oluwatobi, 2012. Output and unemployment relationship: How applicable is the Okun's law to Nigeria? Available from SSRN: http://ssrn.com/abstract=2512898.

Rafindadi, A.S. (2012) Macroeconomic Policy, Output and Unemployment Dynamics in Nigeria: Is There Evidence of Jobless Growth? Paper presented at the 53th Annual conference of the Nigerian economic society on "Youth Employment and Poverty Reduction in Nigeria". NICON Luxury Hotel, Abuja. 


\section{APPENDIX}

\section{Table 1: ARDL Bound Test Result}

Wald Test:

Equation: Untitled

\begin{tabular}{lccc}
\hline \hline Test Statistic & Value & $\mathrm{df}$ & Probability \\
\hline \hline F-statistic & 0.655646 & $(3,26)$ & 0.5867 \\
Chi-square & 1.966938 & 3 & 0.5793 \\
\hline \hline
\end{tabular}

Null Hypothesis: $C(5)=C(6)=C(7)=0$

Null Hypothesis Summary:

\begin{tabular}{lcc}
\hline \hline Normalized Restriction $(=0)$ & Value & Std. Err. \\
\hline \hline C(5) & -0.029606 & 0.066660 \\
C(6) & -0.028062 & 0.104469 \\
C(7) & -0.039774 & 0.028623 \\
\hline \hline
\end{tabular}

Restrictions are linear in coefficients. 
Table 2: Vector Autoregressive (VAR) Result.

System: UNTITLED

Estimation Method: Least Squares

Date: 07/26/16 Time: 06:38

Sample: 19812014

Included observations: 34

Total system (balanced) observations 102

\begin{tabular}{rrrrr}
\hline \hline & Coefficient & Std. Error & t-Statistic & Prob. \\
\hline \hline $\mathrm{C}(1)$ & 0.992020 & 0.054956 & 18.05104 & 0.0000 \\
$\mathrm{C}(2)$ & -0.049630 & 0.053900 & -0.920779 & 0.3596 \\
$\mathrm{C}(3)$ & -0.028941 & 0.022832 & -1.267583 & 0.2082 \\
$\mathrm{C}(4)$ & 1.541895 & 0.895246 & 1.722315 & 0.0884 \\
$\mathrm{C}(5)$ & 0.233354 & 0.170918 & 1.365300 & 0.1756 \\
$\mathrm{C}(6)$ & -0.295362 & 0.167632 & -1.761969 & 0.0815 \\
$\mathrm{C}(7)$ & -0.047107 & 0.071009 & -0.663396 & 0.5088 \\
$\mathrm{C}(8)$ & 4.455495 & 2.784268 & 1.600239 & 0.1131 \\
$\mathrm{C}(9)$ & -0.611123 & 0.366383 & -1.667991 & 0.0988 \\
$\mathrm{C}(10)$ & 0.483713 & 0.359339 & 1.346121 & 0.1816 \\
$\mathrm{C}(11)$ & 0.509344 & 0.152216 & 3.346192 & 0.0012 \\
$\mathrm{C}(12)$ & 13.49351 & 5.968414 & 2.260821 & 0.0262 \\
\hline \hline
\end{tabular}

Equation: UNEM $=\mathrm{C}(1) * \mathrm{UNEM}(-1)+\mathrm{C}(2) * \mathrm{RGDP}(-1)+\mathrm{C}(3) * \operatorname{INFL}(-1)+\mathrm{C}(4)$

Observations: 34

\begin{tabular}{llll}
\hline R-squared & 0.933649 & Mean dependent var & 10.12353 \\
Adjusted R-squared & 0.927013 & S.D. dependent var & 7.656055 \\
S.E. of regression & 2.068361 & Sum squared resid & 128.3436 \\
Durbin-Watson stat & 1.842202 & &
\end{tabular}

Equation: RGDP $=\mathrm{C}(5) * \mathrm{UNEM}(-1)+\mathrm{C}(6) * \operatorname{RGDP}(-1)+\mathrm{C}(7) * \operatorname{INFL}(-1)+\mathrm{C}(8)$

Observations: 34

\begin{tabular}{llll}
\hline R-squared & 0.154576 & Mean dependent var & 4.489118
\end{tabular}

$\begin{array}{llll}\text { Adjusted R-squared } & 0.070033 & \text { S.D. dependent var } & 6.670547\end{array}$

S.E. of regression $\quad 6.432728$ Sum squared resid 1241.400

Durbin-Watson stat 1.983028

Equation: INFL $=\mathrm{C}(9) * \operatorname{UNEM}(-1)+\mathrm{C}(10) * \mathrm{RGDP}(-1)+\mathrm{C}(11) * \operatorname{INFL}(-1)+$ $\mathrm{C}(12)$

Observations: 34

\begin{tabular}{llll}
\hline R-squared & 0.423242 & Mean dependent var & 19.90294 \\
Adjusted R-squared & 0.365567 & S.D. dependent var & 17.31212 \\
S.E. of regression & 13.78933 & Sum squared resid & 5704.368
\end{tabular}

Durbin-Watson stat $\quad 1.626036$ 